Journal of

Strategic Management

(JSM)

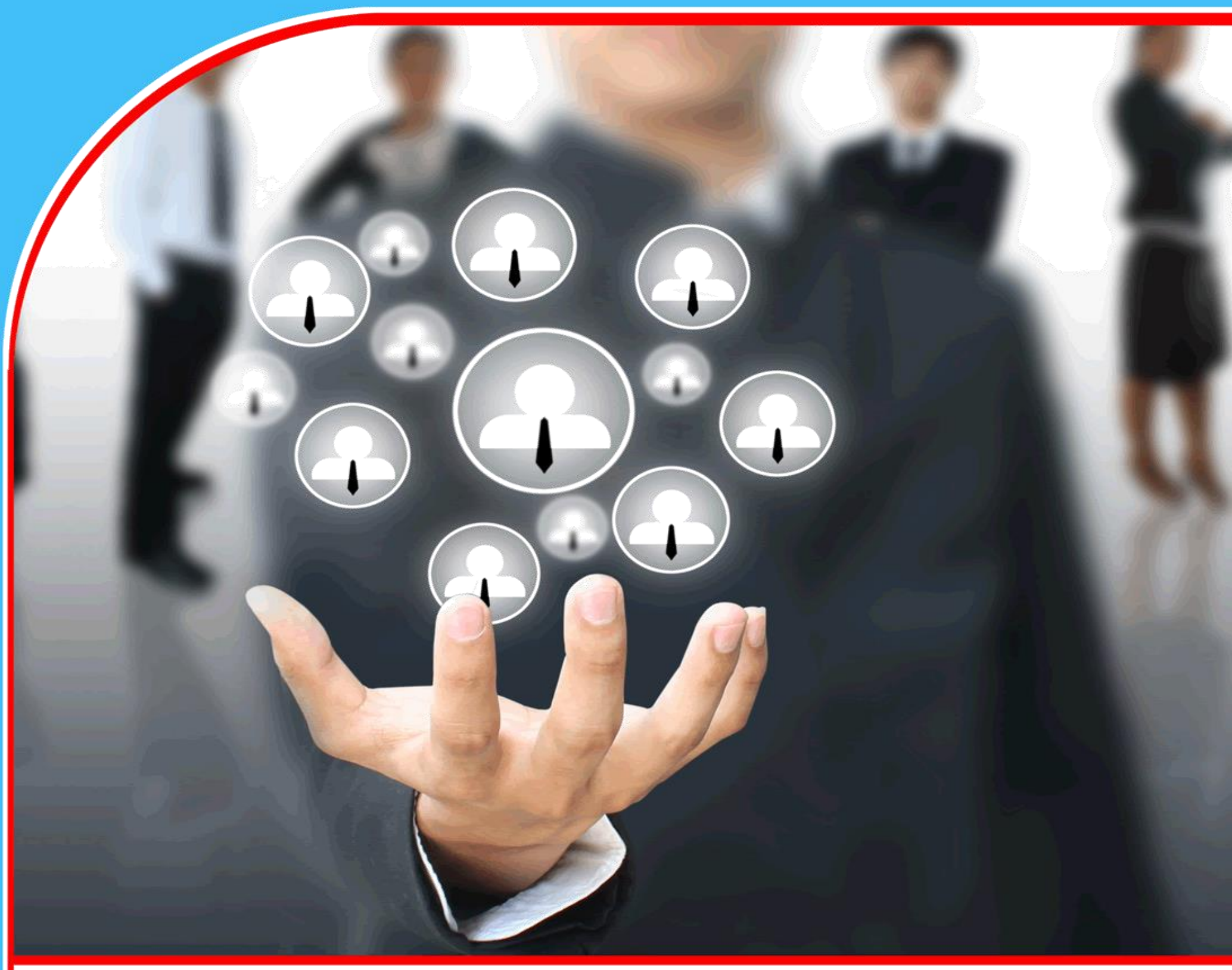

INTERNATIONAL MARIET ENTRY STRATEGIES, ORGANIZATIONAL CHARACTERISTICS AND THE PERFORMANCE OF MANUFACTURING FIRMS IN KENYA

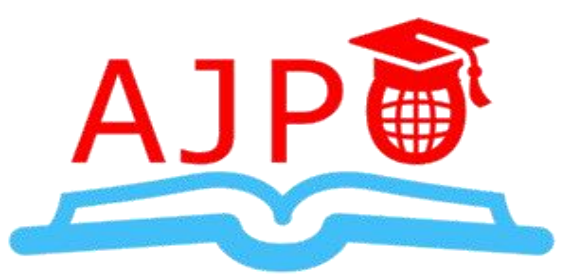




\title{
INTERNATIONAL MARKET ENTRY STRATEGIES, ORGANIZATIONAL CHARACTERISTICS AND THE PERFORMANCE OF MANUFACTURING FIRMS IN KENYA
}

\author{
$1 *$ Ken Sukali \\ 1*Post graduate student \\ University of Nairobi \\ *Corresponding Author's Email: ksukali@gmail.com \\ ${ }^{2}$ Dr.R. Musyoka \\ Lecturer, University of Nairobi
}

\begin{abstract}
Purpose: The main purpose of this study was on the influence of international market entry strategies on the performance of manufacturing multinationals in Kenya.

Methodology: The research design used in this study was descriptive research design. There are 213 Multinational Corporations in Kenya. Out of the 213 Multinational Corporations, 108 firms are in the manufacturing sector and are located in Nairobi. The population of the study was 108 firms. The sampling frame was retrieved from Mars Group Kenya. It is for this reason that the study considered $50 \%$ of the population. This yielded 54 firms. The study used a questionnaire as the preferred data collection tool. Descriptive statistics included frequencies and measures of central tendency mainly means and frequencies. Inferential statistics included regression modeling, t-test and Analysis of Variance (ANOVA).

Results: Results indicated that manufacturing multinationals used various international market strategies to venture into business. These strategies include licensing; further indicated that the firms used these market strategy entries to a large extent. Regression results indicated that market entry strategies had an influence on performance of the firm (ROA)

Unique contribution to theory, practice and policy: The study recommends that the management to evaluate the factors to consider when choosing an entry strategy thoroughly so as to make sure they know the market very well and that the management to evaluate the factors influencing the choice of market entry modes. This is to ensure that they choose the best mode.
\end{abstract}

Key words: International market, performance, manufacturing firms 


\subsection{INTRODUCTION}

\subsection{Background of the Study}

The strides made by African economies in achieving economic growth must be accompanied by efforts to boost long-term competitiveness if the continent is to ensure sustainable improvements in living standards. Regional integration is a key vehicle for helping Africa to raise competitiveness, diversify its economic base and create enough jobs for its young, fasturbanizing population (Africa Competitiveness Report, 2013). To this end, the Kenyan Government and other East African governments have been at the forefront of enhancing integration through the East Africa Community. The East African Community (EAC) reemerged in 2000 after the ratification of the EAC treaty signed earlier in 1999 by member states of Kenya Uganda and Tanzania. Rwanda and Burundi joined the union in 2007. It is commonly believed that the East African community will facilitate the entry of manufacturing and nonmanufacturing enterprises in the partner states.

The study is backed by various theories such as institutional theory, absolute advantage theory and new trade theory. Institutional theory typically focuses on the pressures exerted by external institutions on the strategies of firms. External institutions may consist of regulatory structures, agencies, laws, courts, professions, interest groups and public opinion (Oliver, 1991). To build legitimacy, organizations must comply with formal and informal rules, norms, behaviors and ceremonies set forth by external institutions in the locations where they operate (Meyer \& Rowan, 1977). In absolute advantage theory, Smith argued that it was impossible for all nations to become rich simultaneously by following mercantilism because the export of one nation is another nation's import and instead stated that all nations would gain simultaneously if they practiced free trade and specialized in accordance with their absolute advantage (Guillory, 2005). New Trade Theory tries to explain empirical elements of trade that comparative advantage-based models above have difficulty with. These include the fact that most trade is between countries with similar factor endowment and productivity levels, and the large amount of multinational production (foreign direct investment) that exists (Shiozawa, 2007).

Companies enter international competitions because of different motives such as gaining global reputation, assurance of long term growth, increase of profitability, reaping the economy of scale and for other reasons such as saturation of internal market, intensity of competition in internal market and pressure of governmental rules and regulations. In international competition, a proper and creative entry strategy guaranties a long term presence in the market and leads to the success of the company in international markets. Those companies, which tend to enter international markets, must decide about the type of entry strategy and its effect on foreign operation of the company (Cateora \& Graham, 2011).

When a firm is going to explore a foreign market, the choice of the best mode of entry is decided by the firm's expansion strategy. The main aim of every business organization is to establish itself in the global market. Thus, the process calls for developing an effective international marketing strategy in order to identify the international opportunities, explore resources and capabilities, and utilize core competencies in order to better implement the overall international strategies. The decision of how to enter a foreign market can have a significant impact on the results. Companies can expand into foreign markets via the following International Market Entry 
Strategies: exporting, licensing, joint venture and direct investment (Meyer, Estrin, Bhaumik, \& Peng, 2009).

All of them have their advantages for the firm to explore as well as disadvantages which must be considered by the firm's top management. "What entry mode that a multinational company chooses has implications for how much resources the company must commit to its foreign operations, the risk that the company must bear, and the degree of control that the company can exercise over the operations on the new market. (Zekiri \& Angelova, 2011)

\subsection{Research Problem}

Mode of entry into an international market is the channel which organization that wants to operate in international markets employs to gain entry to a new international market. The choice for a particular entry mode is a critical determinant in the successful running of a foreign operation (Erramilli \& Rao, 1993). However, it may seem that the use of particular strategies by international firms may yield higher growth and performance than others (Lages \& Montgomery, 2012).

Kenya has the biggest formal manufacturing sector in East Africa. This sector has grown over time both in terms of its contribution to the country's Gross Domestic Product and employment. It is evident from these trends that the sector makes an important contribution to Kenya's economy. The industrial sector's share of monetary GDP has remained about $15-16 \%$ while that of manufacturing sector has remained at a little more than $10 \%$ over the last two decades. Manufacturing activities account for the greatest share of industrial production output and form the core of industry. Manufacturing sector makes an important contribution to the Kenyan economy and currently employs 254,000 people, which represents 13 per cent of total employment with an additional 1.4 million people employed in the informal side of the industry. The performance of the multinationals manufactures in Kenya has been on the rise and it is important to explore the influence of market entry strategies on the financial performance of multinational firms in Kenya.

Studies on the relationship between the choice of international market entry strategy and firm performance are abundant at global level. A case study that focused on mode of entry strategies that would be used by a Finnish firm, YIT Group to enter a developing country, Kenya. Mugendi (2010) investigated the Equity Bank's foreign market entry strategies into Southern Sudan and Uganda. Ngetich (2010) investigated the strategies adopted by Kenya Commercial Bank to gain entry into East Africa Region Financial Market. Wachari (2010) conducted a study on the determinants of Foreign Entry Strategies adopted by Kenya Firms in selecting and entering international markets. However, none of the local studies focus on the multinational manufacturing subsector.

\subsection{Study Objectives}

i) To determine and establish the motive behind the choice of market entry strategies by manufacturing multinationals in Kenya

ii) To examine the influence of market entry strategies and organizational characteristics on the performance of manufacturing multinationals in Kenya 


\subsection{LITERATURE REVIEW}

\subsection{Theories on International Market Entry Strategies}

The study is hinged on various theories; these are institutional Theory, Absolute advantage Theory and New trade Theory.

\subsubsection{Institutional Theory}

Institutional theory typically focuses on the pressures exerted by external institutions on the strategies of firms. External institutions may consist of regulatory structures, agencies, laws, courts, professions, interest groups and public opinion (Oliver, 1991). To build legitimacy, organizations must comply with formal and informal rules, norms, behaviors and ceremonies set forth by external institutions in the locations where they operate (Meyer \& Rowan, 1977). Hence, institutional theorists emphasizing the value of conformity to the external environment suggest that firms need to be similar, or isomorphic, to their environment and surrounding agents to survive and prosper (DiMaggio \& Powell, 1983). Isomorphism through mimicry is a strategic choice whereby one firm enhances its legitimacy in a population by resembling other incumbent firms facing the same set of environmental conditions. In fact, recent research primarily highlights legitimacy arguments and mimicking effects, with the latter operationalized as an imitation of incumbent firms or market leaders (DiMaggio \& Powell, 1983).

\subsubsection{Absolute Advantage Theory}

The principle of absolute advantage refers to the ability of a party (an individual, or firm, or country) to produce more of a good product or service than competitors, using the same amount of resources (O'Sullivan \& Sheffrin, 2003). Adam Smith first described the principle of absolute advantage in the context of international trade, using labor as the only input. Since absolute advantage is determined by a simple comparison of labor productivities, it is possible for a party to have no absolute advantage in anything; (Marrewijk, 2007) in that case, according to the theory of absolute advantage, no trade will occur with the other party (Harrington, 2009). It can be contrasted with the concept of comparative advantage which refers to the ability to produce specific goods at a lower opportunity cost.

The main concept of absolute advantage is generally attributed to Adam Smith for his 1776 publication An Inquiry into the Nature and Causes of the Wealth of Nations in which he countered mercantilist ideas (Marrewijk, 2007). Smith argued that it was impossible for all nations to become rich simultaneously by following mercantilism because the export of one nation is another nation's import and instead stated that all nations would gain simultaneously if they practiced free trade and specialized in accordance with their absolute advantage (Guillory, 2005). Smith also stated that the wealth of nations depends upon the goods and services available to their citizens, rather than their gold reserves (Harrington, 2009). While there are possible gains from trade with absolute advantage, the gains may not be mutually beneficial. Comparative advantage focuses on the range of possible mutually beneficial exchanges.

\subsection{International Market Entry Strategies}

International market entry modes can be classified according to level of control, resource commitment, and risk involvement (Anderson \& Gatignon, 2012; Erramilli \& Rao, 2013; Hill, Hwang \& Kim, 1990). For example, in a study of the international operations of service firms in 
the United States, Erramilli and Rao (2013) classify market entry modes into two categories based on their level of control-full-control (i.e. wholly owned operation) and shared-control mode (i.e. contractual transfer or joint venture).

Many forms of market entry strategy are available to firms to enter international markets. One classification first distinguishes between equity and non-equity modes. Equity modes involve firms taking some degree of ownership of the market organizations involved, including wholly owned subsidiaries and joint ventures. Non-equity modes do not involve ownership and include exporting or some form contractual agreements such as licensing or franchising (Wilkinson \& Nguyen, 2011).

International market entry modes can be classified according to level of control, resource commitment, and risk involvement (Hill, Hwang \& Kim, 1990). For example, in a study of the international operations of service firms in the United States, Erramilli \& Rao (1993) classify market entry modes into two categories based on their level of control-full-control (i.e. wholly owned operation) and shared-control mode (i.e. contractual transfer or joint venture).

The classification system adopted by Kim and Hwang (1992) is three fold: licensing, joint ventures and wholly owned subsidiaries. Kim and Hwang believe that these methods provide three distinctive levels of control and require different levels of resource commitment. Kwon and Konopa (1993) indicate that each foreign market entry mode is associated with advantages and disadvantages in terms of risk, cost, control, and return. Their study was designed to examine the impacts of a series of determinants on the choice of foreign production and exporting adopted by 228 U.S. manufacturing firms. Agarwal and Ramaswami (1992) suggest that the most commonly used entry modes are exporting, licensing, joint venture and sole venture. These methods involve varying levels of resource commitment.

Cateora and Graham (2011) stated there are six basic strategies for entering a new market: export/import, licensing and franchising, joint venturing, consortia, partially-owned subsidiaries, and wholly-owned subsidiaries. Generally, these represent a continuum from lowest to highest investment and concomitant risk-return potential. In choosing a particular strategy, a company constructs a fit between its internal corporate risk "comfort level" and the externally-perceived risk level of the target entry market. Two companies may perceive different risks as they evaluate the same market and therefore choose different entry modes. Two companies also may perceive the same risks in a country but still choose different strategies because of their firm's differing tolerances of risk. More specifically, the different market-entry strategies can be encapsulated as follows.

Karkkainen (2011) suggest that the initial classification of different international entry modes is founded on two separate characteristics; the location of manufacturing facilities, and the percentage of ownership the firm desire in foreign investment. Entry in the foreign markets can occur in two ways based on the location of the manufacturing facilities. The firm can either export its products to the target country from production facilities outside that country (exporting strategies), or the firm can transfer its resources in technology, capital, human skills, and enterprise to the foreign country, where they may be sold directly to users or combined with local resources to manufacture products for sale in local market (non-exporting strategies). The second characteristic (percentage of ownership) offers three different options; none, partly or wholly owned investment. 
Tallman and Fladmoe-Lindquist (2012) suggest that joint ventures have also been noted as vehicles for learning since cooperation with a local partner provides the focal firm an opportunity to utilize the partner's local market knowledge and social and business ties. In addition, joint ventures allow technological advancement through the transfer of technologies among partners. In contrast, contractual agreements (i.e., licensing, $R \& D$ contracts, alliances, etc.) often involve explicit descriptions of technologies intended to be learned by one party.

Ndegwa and Otieno (2010) conducted a study on market entry strategies for a transition country, Kenya, a case study that focused on mode of entry strategies that would be used by a Finnish firm, YIT Group to enter a developing country, Kenya. The focus was on motives to enter developing countries, the strategies used to enter developing countries, the factors influencing the decision of entry strategy, and finally problems facing companies entering developing markets experience. The study concluded that the most significant motive to enter developing countries is potential growth of the market, the most suitable entry mode strategy is joint venture, the most significant factor influencing the entry mode decision is the legal framework, and the largest problem experienced by companies investing in the country is bureaucracy.

\subsection{International Market Entry Strategies and Organizational Performance of Multinationals}

The choice of entry mode has become a crucial strategy decision for firms wishing to enter international markets, as it will have an important influence on their future business success (Peinado \& Barber, 2009). Market entry strategies affect business performance in the context of manufacturing industries (Kirca, 2011). Choosing the right entry strategies is one of the key points in international marketing. These strategies have an effect on performance and duration of it through determining the method and allocating essential and sufficient resources (Ekeledo \& Sivakumar, 2013).

Entry mode performance is defined in terms of efficiency or profitability. Nonprofit motives, such as resource and knowledge development or strategic moves against competitors, are assumed to be reflected in long term profit. Profitability depends on costs and revenues (Wilkinson and Nguyen, 2011). Furthermore, some of the researches indicate that entry strategies affect export performance by determining the control level, risk level and company share in foreign markets and end up with the success or failure of the company (Kock et al., 2014).

Previous studies have generally neglected the link between exporting and performance and survival. An exception is the study conducted by McDougall and Oviatt (2010). Their longitudinal study of 62 new manufacturing firms in the USA engaged in the computer and communications industries revealed that ventures that had increased international sales, compared to those that had not, exhibited superior performance in terms of both relative market share and return on investment (ROI). However, their study was conducted over only a 2-year period and focused solely upon a relatively small sample of manufacturing firms. Westhead (2009), during his cross-sectional study of new firms in Great Britain, focused upon the performance of firms engaged in manufacturing and producer services activities. He found that exporting firms recorded significantly higher levels of absolute growth since the businesses had received their first orders than did non exporting firms (Westhead et al, 2009). 


\subsection{Organization Characteristics}

Research on entry strategy has identified a firm's level of involvement or control over an operation and resource commitment as critical dimensions upon which entry strategies can be categorized (Kogut \& Singh, 2012; Treadgold, 2013). Treadgold (2013) distinguishes between three main entry strategies. First, an entry strategy that affords a high degree of control is normally associated with high cost, such as acquisition, dominant shareholding or wholly owned greenfield investments. The second strategy involves medium cost and control, which is typically connected with 50:50 joint ventures. Third, a low cost strategy is said to imply a reduction in control, such as minority equity interests, franchise arrangements and in-store concessions.

Organizational culture is a critical factor in determining a firm's corporate strategy and direction. Consequently, it is an important variable when examining a firm's entry strategy. Organizations can be classified as one of four cultures (Deshpande et al., 2014). First, a hierarchical culture emphasizes established procedures, rules and uniformity. Second, the clan culture stresses loyalty, tradition and commitment to the firm. Third, the market culture focuses on competitive actions and achievement. Fourth, an organization with an adhocracy culture is entrepreneurial, creative and flexible. In his study of organizational culture as an antecedent to the export intention of firms Dosoglu-Guner (2013) found that a clan culture decreases and an adhocracy culture increases a firm's probability of exporting to a foreign market. The logic provided by Dosoglu-Guner's (2013) study and Deshpande et al's. (2012) classification of organizational cultures suggests a positive relationship between organizational culture and entry strategy

International experience has been shown to have important implications for entry strategy selection (Anderson \& Gatignon, 2012; Caves, 2013). It is argued that as firms gain more international experience the level of uncertainty regarding operating in foreign markets will reduce, which, in turn, increases the likelihood that such firms will use high cost/high control entry strategies. Correspondingly, those firms with less international experience are more likely to enter a foreign market through a joint venture as a means of sharing the risks and responsibility (Caves, 2013).

In terms of firm size, White (2011) suggests that larger retailers, with greater financial resources, are more likely to use acquisition as a mode of entry, whereas small retailers will evaluate the relative benefits of franchising, concessions, distributors and agents. This positive relationship between firm size and entry strategy is supported by the export literature which has found a strong association between firm size and high cost/high control entry strategies (Caves, 2013; Erramilli and Rao, 1993; Kogut and Singh, 2012).

\subsection{RESEARCH METHODOLOGY}

The research design used in this study was descriptive research design. There are 213 Multinational Corporations in Kenya. Out of the 213 Multinational Corporations, 108 firms are in the manufacturing sector and are located in Nairobi. The population of the study is therefore 108 firms. The sampling frame was retrieved from Mars Group Kenya. It is for this reason that the study considered $50 \%$ of the population. This yielded 54 firms. The study used a questionnaire as the preferred data collection tool. Descriptive statistics included frequencies and measures of central tendency mainly means and frequencies. Inferential statistics included regression modeling, t-test and Analysis of Variance (ANOVA). 


\subsection{DATA ANALYSIS}

\subsection{Firm Characteristics}

This section presents the firm characteristics results. The results are presented in pie charts.

\subsubsection{Length of Period in Operation}

The respondents were asked to indicate the length of period of their firms in operation in Kenya. Majority (60\%) of the respondents indicated over 10 years while $20 \%$ of the respondents indicated 6-10 years and 19\% of the respondents indicated 2 to 5 years. The findings imply that the organizations had existed for a long period and hence they have enough experience on the use of market entry strategies.

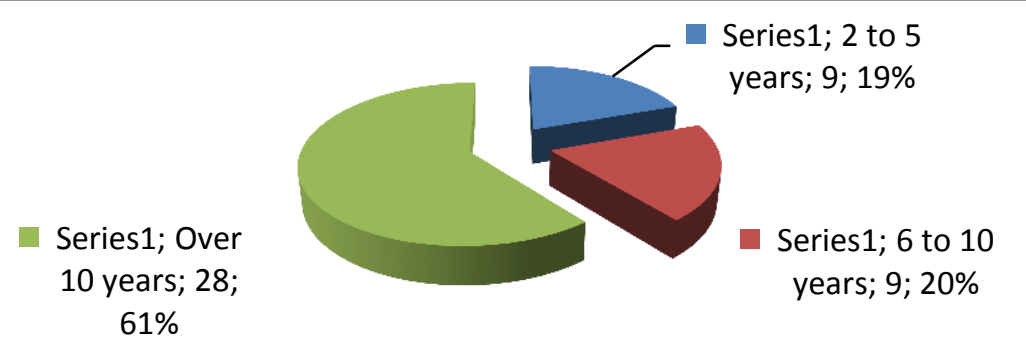

\section{Figure 4.1: Length of Period in Operation}

\subsubsection{Listing Status}

The respondents were asked to indicate the listing status of the companies. Results in Figure 4.2 indicate that $70 \%$ of the respondents indicated not listed while $30 \%$ indicated listed. The findings may have an implication on the choice of market entry strategies. In addition, listed firms may have different motivations and factors affecting their choice of market entry strategies compared to non listed firms.

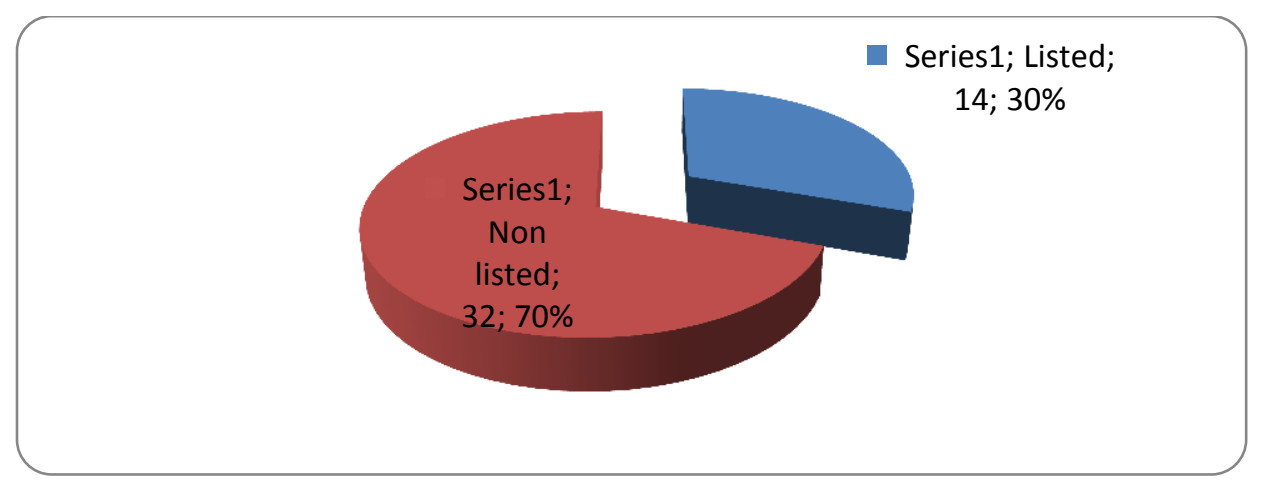

\section{Figure 4.2: Listing Status}

\subsubsection{Number of Employees}

The respondents were asked to indicate the number of the employees in the companies. Results in figure 4.3 revealed that majority (74\%) of the respondents indicated over 150 employees while 
$26 \%$ indicated 51 to 150 employees. The findings imply that the organizations were large enough and that they fell into the categories of large business.

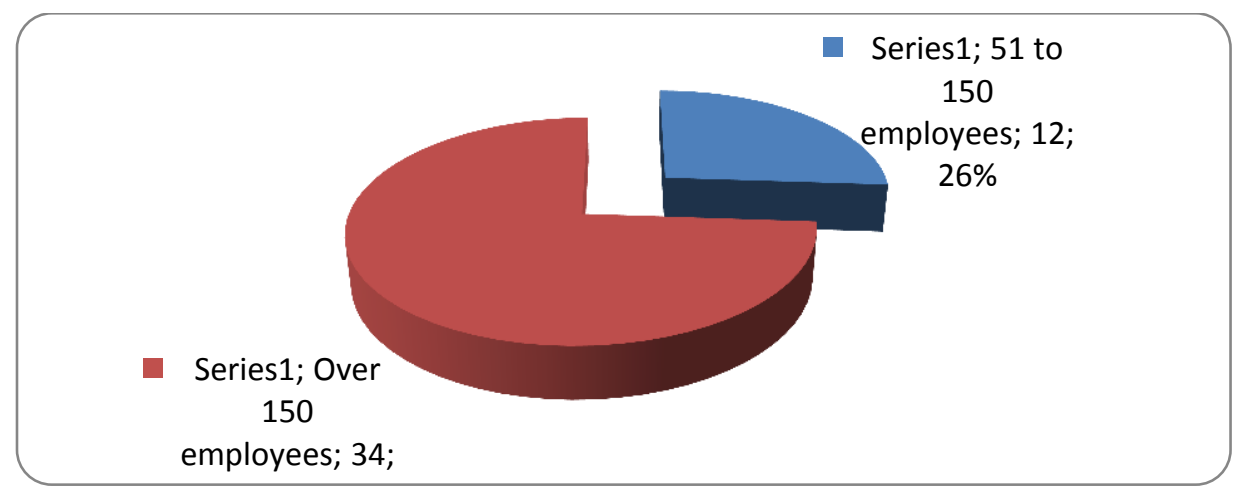

\section{Figure 4.3: Number of Employees}

\subsubsection{Type of Culture}

The respondents were asked to indicate the type of culture for their companies. Figure 4.4 reveals that $48 \%$ of the respondents indicated they had hierarchical type of culture while $20 \%$ indicated adhocracy culture and $15 \%$ indicated market culture.

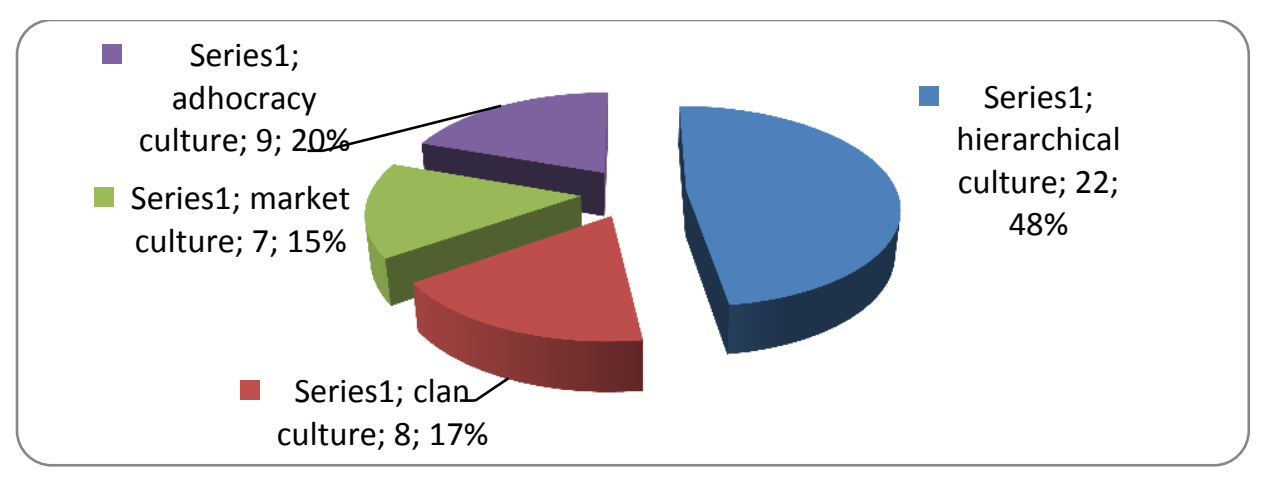

Figure 4.4: Type of Culture

\subsection{Descriptive Results}

This section presents the descriptive results for the dependent variable and independent variables. The results are presented in frequency tables and trend graphs.

\subsubsection{Non-Equity Based Strategy}

The study sought to find out the non-equity based strategies that the companies use. Table 4.1shows that $82.6 \%$ of the respondents agreed that their organization used licensing mode of international marketing strategy to venture into multinationals, $73.9 \%$ agreed that their organization used wholly owned subsidiaries mode of international marketing strategy to venture into multinationals and $80.4 \%$ agreed that their organization used exporting mode of international marketing strategy to venture into multinationals. The mean score of responses for this section was 3.88 which indicate that majority of the respondents agreed with the statements regarding non-equity market based strategy of multinational firms in Kenya. The findings imply 
that the manufacturing firms in Kenya use several market entry strategies. The finding also imply that manufacturing firms in Kenya do not rely on only one market entry strategies since there are gains to be made and advantages to be exploited when using different market entry strategies.

Table 4.1: Non-Equity Based Strategy

\begin{tabular}{lcccccc}
\hline Statement & $\begin{array}{c}\text { Strongly } \\
\text { disagree }\end{array}$ & $\begin{array}{c}\text { Disagr } \\
\text { ee }\end{array}$ & $\begin{array}{c}\text { Neutra } \\
\text { l }\end{array}$ & $\begin{array}{c}\text { Agree } \\
\text { Strongly } \\
\text { agree }\end{array}$ & $\begin{array}{c}\text { Likert } \\
\text { Mean }\end{array}$ \\
\hline $\begin{array}{l}\text { My organization used licensing } \\
\text { mode of international marketing } \\
\text { strategy to venture into } \\
\text { multinationals, }\end{array}$ & $17.4 \%$ & $0.0 \%$ & $0.0 \%$ & $56.5 \%$ & $26.1 \%$ & 3.74 \\
$\begin{array}{l}\text { My organization used wholly } \\
\text { owned subsidiaries mode of } \\
\text { international marketing strategy } \\
\text { to venture into multinationals. }\end{array}$ & $15.2 \%$ & $6.5 \%$ & $4.3 \%$ & $30.4 \%$ & $43.5 \%$ & 3.8 \\
$\begin{array}{l}\text { My organization used exporting } \\
\text { mode of international marketing } \\
\text { strategy to venture into } \\
\text { multinationals. }\end{array}$ & $10.9 \%$ & $0.0 \%$ & $4.3 \%$ & $37.0 \%$ & $47.8 \%$ & 4.11 \\
\begin{tabular}{l} 
Average \\
\hline
\end{tabular} & & & & & & \\
\hline
\end{tabular}

\subsubsection{Equity Based Strategy}

The respondents were asked to indicate the equity based strategy used in their organizations. Results on Table 4.2 indicate that $93.5 \%$ of the respondents agreed that their organization used Franchising mode of international marketing strategy to venture into multinationals, while $76.1 \%$ agreed that their organization used Joint Venture mode of international marketing strategy to venture into multinationals and $67.4 \%$ agreed that their organization used direct Investment mode of international marketing strategy to venture into multinationals. The mean score of responses for this section was 3.88 which indicate that majority of the respondents agreed with the statements regarding equity market based strategy of multinational firms in Kenya. The findings imply that the manufacturing firms in Kenya use several market entry strategies. The finding also imply that manufacturing firms in Kenya do not rely on only one market entry strategies since there are gains to be made and advantages to be exploited when using different market entry strategies. 
Journal of Strategic Management

ISSN 2520-0461(Online)

Vol.1, Issue 2 No.4, pp 68-85, 2017

Table 4.2: Equity Based Strategy

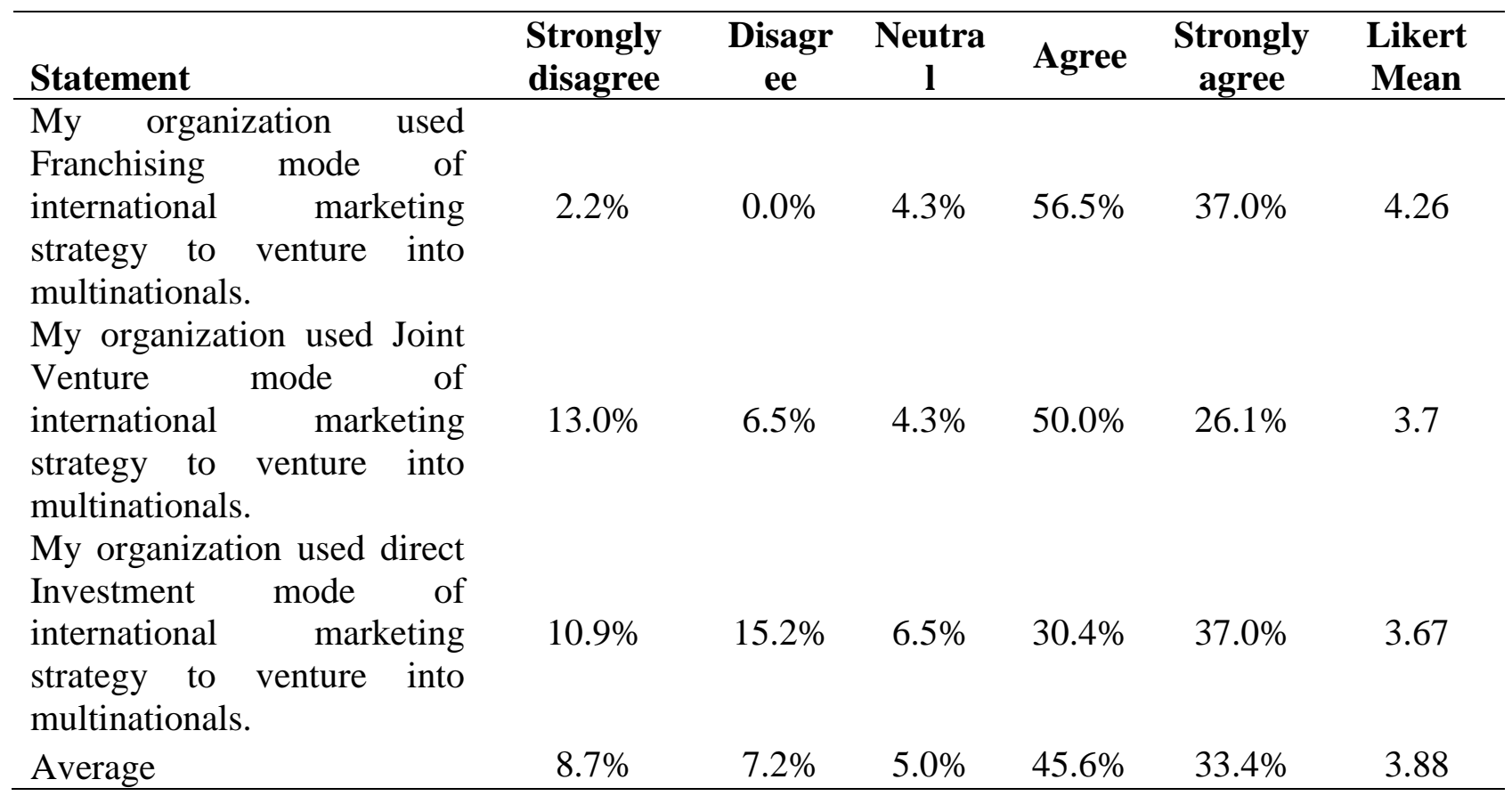

\subsubsection{Size of Firm}

The study sought to find out the influence of size of firm on the performance of manufacturing multinationals in Kenya. Table 4.3 shows that $73.8 \%$ of the respondents agreed that their organization believes that small boards have more favorable performance, $82.6 \%$ agreed that coordination and communication problems impede company performance when the number of directors increases and $73.6 \%$ of the respondents agreed that decision-making problems impede company performance when the number of directors increases. The mean score for responses in this section was 4.03 which indicate that majority of the respondents agreed that size of the firm was a key determinant of company performance of multinational manufacturing firms. 
Journal of Strategic Management

ISSN 2520-0461(Online)

Vol.1, Issue 2 No.4, pp 68-85, 2017

Table 4.3: Size of Firm

\begin{tabular}{|c|c|c|c|c|c|c|}
\hline Statement & $\begin{array}{l}\text { Strongly } \\
\text { disagree }\end{array}$ & $\begin{array}{c}\text { Disagr } \\
\text { ee }\end{array}$ & $\underset{l}{\text { Neutra }}$ & Agree & $\begin{array}{c}\text { Strongly } \\
\text { agree }\end{array}$ & $\begin{array}{l}\text { Likert } \\
\text { Mean }\end{array}$ \\
\hline $\begin{array}{l}\text { My organization believes that } \\
\text { small boards have more } \\
\text { favorable performance }\end{array}$ & $6.5 \%$ & $8.7 \%$ & $10.9 \%$ & $26.1 \%$ & $47.8 \%$ & 4 \\
\hline $\begin{array}{l}\text { Coordination } \\
\text { communication and } \\
\text { impede company performanse } \\
\text { when the number of directors } \\
\text { increases }\end{array}$ & $2.2 \%$ & $8.7 \%$ & $6.5 \%$ & $28.3 \%$ & $54.3 \%$ & 4.24 \\
\hline $\begin{array}{l}\text { Decision-making problems } \\
\text { impede company performance } \\
\text { when the number of directors } \\
\text { increases }\end{array}$ & $2.2 \%$ & $17.4 \%$ & $6.5 \%$ & $41.3 \%$ & $32.6 \%$ & 3.85 \\
\hline Average & $3.6 \%$ & $11.6 \%$ & $8.0 \%$ & $31.9 \%$ & $44.9 \%$ & 4.03 \\
\hline
\end{tabular}

\subsubsection{International Experience}

The study sought to find out the effect of international experience on the performance of manufacturing multinationals in Kenya. Results on Table 4.4 show that $71.7 \%$ of the respondents agreed that their organization had international experience hence improved performance and $71.8 \%$ agreed that their organization had resources available hence improved performance. The mean score for responses in this section was 3.85 which indicate that majority of the respondents agreed that international experience was a key determinant of company performance of multinational manufacturing firms.

Table 4.4: International Experience

\begin{tabular}{|c|c|c|c|c|c|c|}
\hline Statement & $\begin{array}{l}\text { Strongly } \\
\text { disagree }\end{array}$ & $\begin{array}{l}\text { Disagre } \\
\text { e }\end{array}$ & $\begin{array}{l}\text { Neutr } \\
\text { al }\end{array}$ & Agree & $\begin{array}{c}\text { Strongly } \\
\text { agree }\end{array}$ & $\begin{array}{l}\text { Likert } \\
\text { Mean }\end{array}$ \\
\hline My organization has & & & & & & \\
\hline $\begin{array}{l}\text { international experience } \\
\text { hence improved performance }\end{array}$ & $6.5 \%$ & $13.0 \%$ & $8.7 \%$ & $32.6 \%$ & $39.1 \%$ & 3.85 \\
\hline $\begin{array}{l}\text { My organization has } \\
\text { resources available hence } \\
\text { improved performance }\end{array}$ & $10.9 \%$ & $10.9 \%$ & $6.5 \%$ & $26.1 \%$ & $45.7 \%$ & 3.85 \\
\hline Average & $8.7 \%$ & $12.0 \%$ & $7.6 \%$ & $29.4 \%$ & $42.4 \%$ & 3.85 \\
\hline
\end{tabular}

\subsubsection{Organizational Culture}

The study sought to establish the influence of organizational culture on the performance of manufacturing multinationals in Kenya. Table 4.5 indicates that $78.2 \%$ of the respondents agreed 
that their organizational culture supports international business, 65.3\% agreed that their company had deep understanding in the operational rule in our industry and 63\% agreed that their company had sufficient recognition on change trends and establishment plans for quick response. The mean score for responses in this section was 3.93 which indicate that majority of the respondents agreed that organizational culture was a key determinant of company performance of multinational manufacturing firms.

Table 4.5: Organizational Culture

\begin{tabular}{|c|c|c|c|c|c|c|}
\hline Statement & $\begin{array}{l}\text { Strongly } \\
\text { disagree }\end{array}$ & $\begin{array}{c}\text { Disagr } \\
\text { ee }\end{array}$ & $\begin{array}{c}\text { Neutra } \\
1 \\
\end{array}$ & Agree & $\begin{array}{c}\text { Strongly } \\
\text { agree }\end{array}$ & $\begin{array}{l}\text { Likert } \\
\text { Mean } \\
\end{array}$ \\
\hline $\begin{array}{l}\text { My organizational culture } \\
\text { supports international business }\end{array}$ & $0.0 \%$ & $6.5 \%$ & $15.2 \%$ & $23.9 \%$ & $54.3 \%$ & 4.26 \\
\hline $\begin{array}{l}\text { Our company has deep } \\
\text { understanding in the } \\
\text { operational rule in our } \\
\text { industry }\end{array}$ & $0.0 \%$ & $21.7 \%$ & $13.0 \%$ & $28.3 \%$ & $37.0 \%$ & 3.8 \\
\hline $\begin{array}{l}\text { Our company has sufficient } \\
\text { recognition on change trends } \\
\text { and establishment plans for } \\
\text { quick response }\end{array}$ & $0.0 \%$ & $21.7 \%$ & $15.2 \%$ & $30.4 \%$ & $32.6 \%$ & 3.74 \\
\hline Average & $0.0 \%$ & $16.6 \%$ & $14.5 \%$ & $27.5 \%$ & $41.3 \%$ & 3.93 \\
\hline
\end{tabular}

\subsubsection{Performance (Return on Asset)}

The study sought to establish the profitability of manufacturing multinational firms in Kenya across a period of five years. Results in Figure 4.5 shows that the average mean of return on asset increased gradually from 1336008513 Kenya shillings in 2008 to 1667501217 shillings in 2009 and a slight decrease to 1392123935 in 2010 and a consistent increase to a peak of 2030365226 shilling in 2012. The findings imply that the profitability of firms increased across the years, most probably due to good market entry strategies.

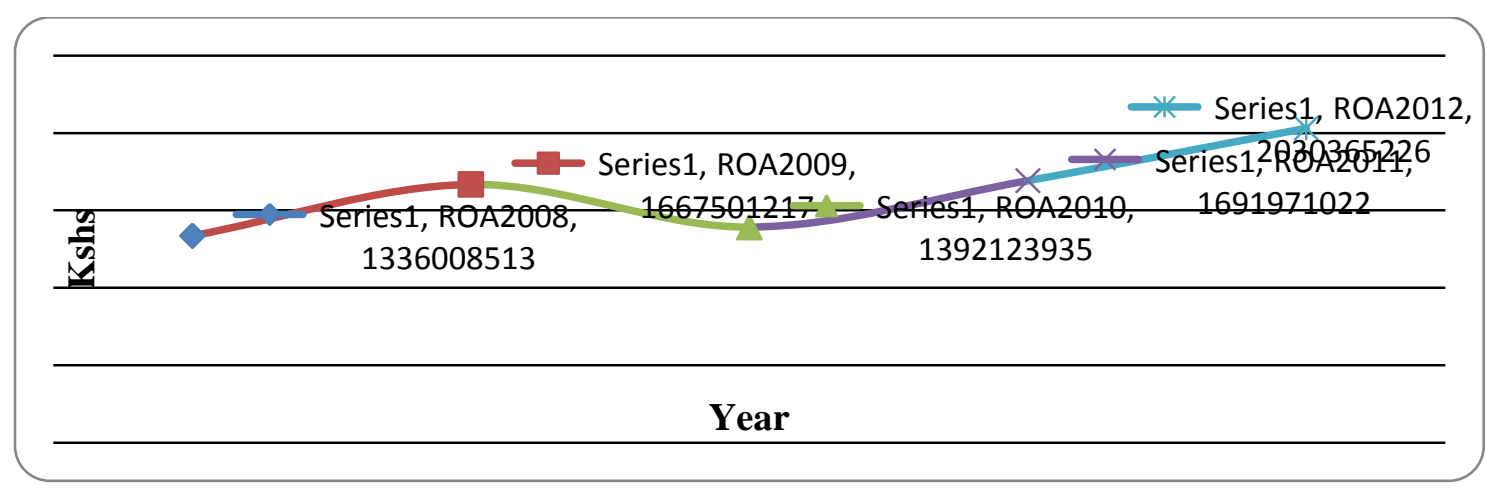

Figure 4.5: Return on Asset 


\subsection{Inferential Statistics}

In order to establish the statistical significance of the independent variables on the dependent variable (performance) regression analysis was employed. The regression equation took the following form.

$$
\begin{aligned}
& y=\beta_{0}+ \beta_{1} X_{1}+\beta_{2} X_{2}+\beta_{3} X_{3}+\beta_{4} X_{4}+\beta_{5} X_{5}+e \\
& Y=\text { Performance } \\
& X_{1}=\text { Equity based Entry Strategies } \\
& X_{2}=\text { Non Equity based Entry Strategies } \\
& X_{3}=\text { Size of firm } \\
& X_{4}=\text { Organizational Culture } \\
& X_{5}=\text { International Experience } \\
& \text { e=error term }
\end{aligned}
$$

In the model $a$ is the constant term while the coefficient $\beta_{1}$ to $\beta_{5}$ are used to measure the sensitivity of the dependent variable $(Y)$ to unit change in the explanatory variable $\left(\mathrm{X}_{1}, \mathrm{X}_{2}, \mathrm{X}_{3}\right.$, $\left.\mathrm{X}_{4}, \mathrm{X}_{5}\right) . \varepsilon$ is the error term which captures the unexplained variations in the model.

Table 4.6 shows that the coefficient of determination also called the $\mathrm{R}$ square is $67.4 \%$. This means that the combined effect of the predictor variables (non-equity based strategy, equity based strategy, size of firm, international experience and organizational culture) explains $67.4 \%$ of the variations in performance of manufacturing multinationals. The correlation coefficient of $82.1 \%$ indicates that the combined effect of the predictor variables have a strong and positive correlation with performance of multinational manufacturing firms.

Table 4.6: Regression Model Fitness

\begin{tabular}{lc}
\hline Indicator & Coefficient \\
\hline $\mathrm{R}$ & 0.821 \\
$\mathrm{R}$ Square & 0.674 \\
Std. Error of the Estimate & 1886062434 \\
\hline
\end{tabular}

Analysis of variance (ANOVA) on Table 4.8 shows that the combine effect of non-equity based strategy, equity based strategy, size of firm, international experience and organizational culture was statistically significant in explaining changes in performance of manufacturing multinational firms. This is demonstrated by a $\mathrm{p}$ value of 0.000 which is less than the acceptance critical value of 0.05 . The results indicated that the overall model was significant, that is, the independent variables were good joint explanatory variables/determinants for performance $(\mathrm{F}=16.531, \mathrm{P}$ value $=0.000)$.

Table 4.7: Analysis of Variance (ANOVA)

\begin{tabular}{lccccc}
\hline Indicator & Sum of Squares & df & Mean Square & F & Sig. \\
\hline Regression & $2.9402 \mathrm{E}+20$ & 5 & $5.88039 \mathrm{E}+19$ & 16.531 & 0.000 \\
Residual & $1.42289 \mathrm{E}+20$ & 40 & $3.55723 \mathrm{E}+18$ & & \\
Total & $4.36309 \mathrm{E}+20$ & 45 & & & \\
\hline
\end{tabular}


Regression results in Table 4.8 indicate that the relationship between profitability and size of firm, international experience and organizational culture is positive and significant while negative and significant with non-equity based strategy and equity based strategy.

Table 4.8: Regression Coefficients

\begin{tabular}{lcccc}
\hline Variable & Beta & Std. Error & t & Sig. \\
\hline Constant & -13794087831 & 2247305402 & -6.138 & 0.000 \\
Non-equity based & -4813059153 & 1245219060 & -3.865 & 0.000 \\
Equity based strategy & -3844066533 & 844697930.4 & -4.551 & 0.000 \\
Size of firm & 7026736235 & 1378741405 & 5.096 & 0.000 \\
International Experience & 3879491581 & 1283886024 & 3.022 & 0.004 \\
Organization Culture & 1665171153 & 693650086.2 & 2.401 & 0.021 \\
\hline
\end{tabular}

\subsection{SUMMARY AND CONCLUSIONS}

\subsection{Conclusions}

From the study, it was possible to conclude that manufacturing multinational firms used more than one market entry strategy to venture into business. This was probably to enhance the firm's performance. It was also possible to conclude that the firms used franchising and exporting to a very large extent and wholly owned subsidiaries, joint venture, licensing and direct investment to a large extent.

It was possible to conclude that the market entry strategy and organizational characteristics influenced the performance of multinational firms. It was possible to conclude that all market entry strategies had a negative and significant relationship with performance of firms and organizational characteristics (size of the firm, international experience and organizational culture) had positive and significant relationship with performance of firms.

\subsection{Recommendations}

Following the study conclusions, it is recommended that the multinationals firms to carry out research on the market entry strategies before venturing into international market. This is to ensure they use the appropriate entry strategy to enhance the organization performance.

The study also recommends that the management to evaluate the factors to consider when choosing an entry strategy thoroughly so as to make sure they know the market very well. It is also recommended that the management to evaluate the factors influencing the choice of market entry modes. This is to ensure that they choose the best mode.

\section{REFERENCES}

Agarwal, S. \& Ramaswami, S. (1992). Choice of foreign market entry mode: impact of ownership, location and internationalization factors, Journal of International Business Studies, Vol. 23 No. 1, pp. 1-27.

Andersen O. \& Gatignon, A. (2012). Firms' internationalization and alternative approaches to the international customer/market selection. International Business Review. Vol. 11 pp. 347363 
Cateora, D. \& Graham, B. (2011). International Marketing,11 Edition, McGraw-Hill

Erramilli, M.K. \& C.P. Rao (1993). Service Firms' International Entry Mode Choice: A Modified Transaction- Cost Analysis Approach. Journal of Marketing 57, 19-38.

Gatignon, H. \& E. Anderson (2009). The Multinational Corporation's Degree of Control Over Foreign Subsidiaries: An Empirical Test of a Transaction Cost Explanation. Journal of Law, Economics and Organization4, 305-336.

Guillory, G. (2005). Comparative Advantage versus Absolute Advantage. Mises Economics Blog. Ludwig von Mises Institute. Archived from the original on 30 April 2009.

Harrington, J. W. (2009). International Trade Theory. Geography 349 Absolute advantage. University of Washington.

Kärkkäinen A. (2011). Selection of International Market Entry Mode, Seminar in Business Strategy and International Business

Kogut, B., and Zander, U. (2012). Knowledge of the Firm, Combinative Capabilities, and the Replication of Technology. Organization Science 3: pp. 383-397.

Lages Luis Filipe, Montgomery David B.( 2012). Export performance as an antecedent of export commitment and marketing strategy adaptation Evidence from small and medium-sized exporters. European Journal of Marketing.Vol. 38.No. 9/10. pp. 1186-1214

Marrewijk, C. (2007). Absolute Advantage. Department of Economics, Erasmus University Rotterdam:world economy. Princeton University Press. Retrieved 2009-05-03.

Meyer, K. E., Estrin, S., Bhaumik, S. and Peng, M. W. (2011). Institutions, resources, and entry strategies in emerging economies (SMJ, forthcoming)

Mugendi, N.G (2010). Equity Bank's Foreign Market Entry Strategies Into Southern Sudan And Uganda. Unpublished MBA Thesis University of Nairobi.

Ndegwa. L and Otieno. K (2010). Market entry strategies for a transition country, Kenya: A case study of yit oyj. Degree Programme in Business Management Thesis. Laurea University

Oliver C. (1991). Sustainable competitive advantage: combining institutional and resource based views. Strategic Management Journal 18: 697-713.

Peinado Esther Sanchez \& Barber Jose Pla (2009). multidimensional concept of uncertainty and its influence on the entry mode choice: An empirical analysis in the service sector. International Business Review. Vol. 15. pp. 215-232

Shiozawa, Y. (2007). A New Construction of Ricardian Trade Theory: A Many-country, Manycommodity with Intermediate Goods and Choice of Techniques. Evolutionary and Institutional Economics Review 3 (2): 141-187. 
Journal of Strategic Management

ISSN 2520-0461(Online)

Vol.1, Issue 2 No.4, pp 68-85, 2017

Tallman, S., \& Yip, G. (2013). Strategy and the Multinational Enterprise. In A.M. Rugman and T. L. Brewer, eds., Oxford Handbook of International Business, Oxford: Oxford University Press. pp. 317-348.

Wilkinson Ian F. \& Nguyen Van (2011). A Contingency Model of Export Entry Mode Performance: The Role of Production and Transaction costs, Australasian Marketing Journal . vol.11 No.3

Zekiri \& Angelova (2011). Factors that Influence Entry Mode Choice in Foreign Markets. European Journal of Social Sciences - Volume 22, Number 4 (2011) 572 